\title{
A Novel Calmodulin Antagonist, CGS 9343B, Modulates Calcium-Dependent Changes in Neurite Outgrowth and Growth Cone Movements
}

\author{
Karen A. Polak, ${ }^{1}$ Arthur M. Edelman, ${ }^{1}$ Jan W. F. Wasley, ${ }^{3}$ and Christopher S. Cohan ${ }^{2}$ \\ 'Department of Pharmacology and Therapeutics and ${ }^{2}$ Department of Anatomical Sciences, School of Medicine and \\ Biomedical Sciences, State University of New York at Buffalo, Buffalo, New York 14214, and 3Pharmaceuticals Division, \\ CIBA-GEIGY Corporation, Summit, New Jersey 07901
}

The neurotransmitter $5-\mathrm{HT}$ alters growth cone motility and neurite elongation in neuron B19, isolated from the buccal ganglion of Helisoma trivolvis (Haydon et al., 1984). The effects of 5-HT are mediated by increases in intracellular calcium levels within the growth cones (Cohan et al., 1987). 5-HT causes a receptor-mediated depolarization of the membrane, which results in the opening of voltage-sensitive calcium channels. The resulting calcium influx decreases both the elongation rate and the total outgrowth of neurites. However, the mechanism(s) mediating these calcium-dependent changes is unclear. As many of the intracellular effects of calcium in eukaryotic cells are mediated by the calcium-binding protein calmodulin, we tested the involvement of such an interaction in the regulation of neurite outgrowth. In these experiments, a new, potent calmodulin antagonist with increased selectivity, CGS 9343B (CGS; Norman et al., 1987), was used to inhibit calmodulin activity during the application of 5-HT to neuron B19.

The addition of $100 \mu \mathrm{m} 5-\mathrm{HT}$ to the culture medium resulted in a significant decrease in the rate of neurite elongation and total neurite outgrowth. Administration of CGS to the culture medium at a concentration $(1.8 \mu \mathrm{M})$ equivalent to its $I \mathrm{C}_{50}$ for calmodulin inhibition completely blocked the inhibitory effects of $100 \mu \mathrm{M} \mathrm{5-HT}$, on both neurite elongation and total neurite outgrowth. CGS alone caused a slight decrease in elongation rate but had no significant effect on total outgrowth. CGS did not block 5-HT-induced electrical activity, indicating that it was not acting as a 5-HT receptor antagonist. Furthermore, measurements of calcium currents obtained from whole-cell patch-clamp recordings demonstrated that CGS did not block membrane calcium channels at concentrations that suppress the effects of 5-HT on neurite outgrowth. These observations suggest that calmodulin mediates some of the effects of increased calcium on neurite elongation and growth cone movements.

\footnotetext{
Received July 9, 1990; revised Oct. 2, 1990; accepted Oct. 5, 1990.

We wish to thank M.-H. Xia, R. S. Saeli, and Z.-H. Zhu for technical assistance and Drs. D. Higgins and P. G. Haydon for helpful discussions. This work was supported by NIII Grants NS24738 to A.M.E. and NS25789 to C.S.C. and by NIH Training Grant GM07145 to K.A.P.

Correspondence should be addressed to Dr. Christopher Cohan, Department of Anatomical Sciences, School of Medicine and Biomedical Sciences, State University of New York at Buffalo, Buffalo, NY 14214

Copyright (c) 1991 Society for Neuroscience $0270-6474 / 91 / 110534-09 \$ 03.00 / 0$
}

Accumulating evidence indicates that neurotransmitters such as $\mathrm{ACh}$, dopamine, and 5-HT play an important role in regulating neuronal growth by acting on specific subsets of neurons to influence both neurite elongation and growth cone movements (Haydon et al., 1984; Mattson et al., 1987; Pearce et al., 1987; Lankford et al., 1988; Mattson, 1988; Patterson, 1988; Lipton and Kater, 1989). One system, which has been studied extensively, is the buccal ganglion of the snail Helisoma trivolvis. In Helisoma, 5-HT selectively inhibits outgrowth of neuron B19, but has no effect on neuron B5 (Haydon et al., 1984). Changes in outgrowth are accompanied by morphological changes in growth cones, including loss of filopodia and retraction of lamellipodia. Similarly, dopamine suppresses outgrowth of B19 while having no effect on B4 or B5 (McCobb et al., 1985, 1988b). Experimental evidence also indicates that neurotransmitters can act locally on growth cones to produce these effects. Isolated growth cones continue to respond selectively to the application of a given transmitter in the same manner as growth cones from intact cells (Haydon et al., 1984; Mattson and Kater, 1987).

In the case of 5-HT, the changes in morphology and outgrowth are initially triggered by 5 -HT-induced alterations in membrane potential. 5-HT depolarizes neuron B19, thereby causing an increase in electrical activity. On the other hand, 5-HT has a small inhibitory effect on B5 membrane potential. This difference presumably accounts for the selectivity of effects of 5-HT in modifying outgrowth of B19 compared with B5. The depolarization by $5-\mathrm{HT}$ is a necessary step for the subsequent effects on outgrowth, as shown by 2 types of experiments. First, application of $\mathrm{ACh}$, which acts as an inhibitory transmitter, and 5-HT simultaneously to B 19 eliminates the excitatory effect of 5-HT on membrane potential and blocks the changes in outgrowth (McCobb and Kater, 1986; McCobb ct al., 1988a). Second, when the depolarizing effects of 5-HT on B19 are blocked directly by a microelectrode-delivered hyperpolarizing current in the soma, the effects of 5-HT on outgrowth are also blocked (McCobb and Kater, 1988).

The mechanism whereby membrane depolarization induced by 5 -HT causes decreased growth has been linked to an increase in cytoplasmic free $\mathrm{Ca}^{2+}$ levels within growth cones (Cohan et al., 1987; Mattson and Kater, 1987). $\mathrm{Ca}^{2+}$ influx occurs through the opening of voltage-sensitive $\mathrm{Ca}^{2+}$ channels in the cell in response to the membrane depolarization. $\mathrm{Ca}^{2+}$ levels, measured with the dye fura-2, have been shown to increase only in those growth cones where outgrowth is blocked by 5-HT (Cohan et al., 1987). The cessation of neurite outgrowth can be mimicked 
with the addition of ionophores such as A23187, which directly increase $\mathrm{Ca}^{2+}$ levels in cells. Furthermore, the presence of $\mathrm{Ca}^{2+}$ channel blockers or reduced extracellular $\mathrm{Ca}^{2+}$ restores neurite elongation by blocking the effects of 5-HT (Mattson and Kater, 1987).

The molecular events that underlie the effects of $\mathrm{Ca}^{2+}$ on neurite elongation and growth cone movements have not yet been identified. $\mathrm{Ca}^{2+}$ may interact directly with cytoskeletal components of the growth cone, such as actin, microtubules, or their associated proteins, and thereby alter motility. Alternatively, $\mathrm{Ca}^{2+}$ may activate $\mathrm{Ca}^{2+}$-binding protein(s), which directly affect intracellular enzymes. Calmodulin (CaM) is the most abundant $\mathrm{Ca}^{2+}$-binding protein and has been established as the primary intracellular $\mathrm{Ca}^{2+}$ receptor in nonmuscle cells (Means et al., 1982; Manalan and Klee, 1984). CaM regulates numerous cellular processes in eukaryotic cells through its $\mathrm{Ca}^{2+}$-dependent control of enzyme activity and protein interactions. The $\mathrm{Ca}^{2+}$ CaM complex has also been demonstrated to regulate the stability of microtubules (Marcum et al., 1978; Job et al., 1981) and binding of some of the microtubule-associated proteins (Sobue et al., 1981).

Effects of CaM in a variety of systems have been studied by the use of available CaM antagonists, including phenothiazines such as the trifluoperazine (TFP) and the naphthalenesulfonamide W-7 (Roufogalis, 1982). These inhibitors have been used extensively to block $\mathrm{Ca}^{2+} / \mathrm{CaM}$-regulated processes in cells under a variety of conditions. Use of both TFP and W-7 to probe the role of $\mathrm{CaM}$ in cellular processes is questionable, however, because of nonspecific effects of these compounds, the most significant of which is their ability to inhibit protein kinase $\mathrm{C}$ (PKC) activity at concentrations comparable to those required for CaM inhibition (Schatzman et al., 1981, 1983). PKC is also activated by increased $\mathrm{Ca}^{2+}$ levels and functions as an alternate $\mathrm{Ca}^{2+}$-sensitive pathway in numerous cell systems. As CaM and PKC both have similar affinities for $\mathrm{Ca}^{2+}$ and are inhibited by CaM antagonists, it is often not possible to discern which molecule is crucial in mediating a particular cellular response. Some $\mathrm{CaM}$ antagonists function as potent antagonists for serotonergic, dopaminergic, muscarinic-cholinergic, or $\alpha$-adrenergic receptors (Roufogalis, 1982). In addition, both TFP and W-7 have been shown to affect voltage-regulated $\mathrm{Ca}^{2+}$ channels in a variety of systems (Bkaily et al., 1984; Clapham and Neher, 1984; Murawsky and Suszkiw, 1984; Greenberg et al., 1987; Doroshenko et al., 1988). In all cases, the extracellular application of these compounds causes a significant, reversible decrease in the peak inward $\mathrm{Ca}^{2+}$ current. Thus, until now, nonspecific effects of the available $\mathrm{CaM}$ blockers have made them of doubtful utility when studying the role of CaM activity.

Recently, a new CaM antagonist, CGS 9343B (CGS), has becn developed that is a potent and selective inhibitor of CaM activity (Norman et al., 1987). CGS is approximately 4 times more potent than TFP as a CaM antagonist and does not affect PKC activity at concentrations up to $100 \mu \mathrm{M}$ (Norman et al., 1987). Furthermore, CGS shows only weak interaction with dopamine receptors. The specificity of CGS as a CaM antagonist makes it a useful tool in the investigation of CaM function in cell systems.

We examined the role of $\mathrm{CaM}$ in regulating the rate of neurite elongation and extent of neurite outgrowth in isolated B19 neurons of Helisoma using CGS. We tested whether CaM mediated the effects of increased intracellular $\mathrm{Ca}^{2+}$ that were evoked by 5-HT application to cultured B 19 neurons. CGS blocked both the decrease in elongation rate and the suppression of neurite outgrowth that resulted from the addition of 5-HT, without affecting either membrane depolarization or inward $\mathrm{Ca}^{2+}$ currents. These data suggest that $\mathrm{CaM}$ is involved in mediating the effects of increased $\mathrm{Ca}^{2+}$ on growth cone motility and neurite outgrowth.

\section{Materials and Methods}

Snail maintenance. Adult specimens of the fresh-water pond snail Helisoma trivolvis were grown from inbred stocks reared in glass aquaria within the laboratory. Tanks were filled with artificial pond water (maintained at $25^{\circ} \mathrm{C}$ ) that was continuously filtered, aerated, and cleaned at regular intervals. Animals were fed daily with trout chow (Purina), lettuce, and carrots. Lighting was maintained on a 12-hr light/dark cycle.

Cell culture. Snails were removed from their shells and placed in sterile saline $(\mathrm{pH}, 7.4)$ with $25 \%$ Listerine to sterilize and anesthetize animals. The buccal ganglia were removed as previously described (Kater and Kaneko, 1972). After dissection, the ganglia were treated at $22^{\circ} \mathrm{C}$ with $0.2 \%$ trypsin for 30 min, followed by 20 min in $0.2 \%$ trypsin inhibitor to facilitate the subsequent removal of individual, identified neurons (Cohan, 1990). Following incubation in trypsin inhibitor, the connective tissue capsule that covers the ganglia was partially dissected using specially sharpened forceps and tungsten microneedles. After visual determination of the location of identified neurons, the neurons were removed individually via suction applied from a sterilized glass micropipette. The cells were plated into a poly-L-lysine (12,000 MW; $0.2 \%$ solution) coated dish containing $2 \mathrm{ml}$ of defined medium (saltfree L-15 medium to which $40 \mathrm{~mm} \mathrm{NaCl}, 1.7 \mathrm{~mm} \mathrm{KCl}, 4.1 \mathrm{~mm} \mathrm{CaCl}_{2}$, $1.5 \mathrm{mM} \mathrm{MgCl}_{2}$, and $10 \mathrm{~mm}$ HEPES, $\mathrm{pH} 7.4$, were added to approximate the ionic composition of snail hemolymph; Gibco special order; Wong et al., 1981).

The identified neuron B19 was used for all experiments. Cells used for determination of elongation rate and total outgrowth were cultured in L-15 that was enriched with conditioning factors from the brain of Helisoma (conditioned medium; Wong et al., 1981). Four brains were added to each $2 \mathrm{ml}$ of defined medium and were incubated at room temperature for $3 \mathrm{~d}$ in a humidified chamber, after which the brains were removed and neurons plated. Neurons in conditioned medium were cultured approximately $18 \mathrm{hr}$ before use to allow the formation of growth cones. Cells used for patch-clamp analysis were plated into defined medium and used within a few hours of isolation, prior to the onset of neurite extension.

Neuronal elongation rates and neurite outgrowth measurements. Isolated, identified B 19 neurons were used to examine the effects of various compounds on neurite elongation rates and total neurite outgrowth. The rate of neurite elongation of B19 was monitored over a 2-hr period after approximately $18 \mathrm{hr}$ in culture. Quantitative measurements of neurite elongation were obtained from time-lapse photographs as described previously (Cohan, 1990). The first $45 \mathrm{~min}$ of each 2 -hr observation period is detined as the baseline period for each growth cone during which neurite elongation was measured for comparison to subsequent treatments. After this period, rates were measured in the presence or absence of 5-HT. When the effect of CGS was studied, it was present during the entire 2-hr observation period. Only growth cones that displayed normal morphology (hroad, flat, phase-dark structures with lamellipodia and filopodia), exhibited steady rates of growth during the baseline period (minimal rate of $8.5 \mu \mathrm{m} / \mathrm{hr}$ ), and grew in a linear path during the 2-hr period were used. Approximately $30 \%$ of the growth cones on a given neuron fulfilled these criteria.

Neurite outgrowth for a given cell was quantified as the average radial distance from the neurite tips to the soma. Twelve radial measurements were averaged from 6 evenly spaced sectors encompassing the soma and neurites. The extent of outgrowth is defined as the change in neurite outgrowth achieved $24 \mathrm{hr}$ after the 2-hr observation period and is expressed as a percentage of the outgrowth from control (untreated) neurons over the same 24-hr period. Neurites of control B 19 neurons completed their outgrowth within $48 \mathrm{hr}$ after plating.

Measurement of electrical activity of neurons. Electrical activity of cultured B19 neurons was measured by extracellular patch recordings from the soma in the cell-attached configuration. This method is less invasive than intracellular microelectrode recordings, which frequently alter spontaneous activity in these neurons (McCobb et al., 1988a). Patch pipettes were pulled on a micropipette puller (Sutter P-30) from $1.65-\mathrm{mm}$ outer diameter Boralex (Dynalab) thin-walled glass. Tips were 
approximately $4-5 \mu \mathrm{m}$ in diameter with an average bath resistance of 1-2 M . Pipette tips were fire polished on a microforge (Narishige) and filled with defined medium. Seal resistances of $100 \mathrm{M} \Omega$ or greater were obtained for each recording. Control experiments were first performed to determine the accuracy of the cell-attached patch technique in assaying spontaneous electrical activity of B19 neurons. Electrical activity of B 19 cell bodies was simultaneously monitored by cell-attached patch electrodes and intracellular microelectrodes. In every case, an action potential recorded with the microelectrode also produced an easily observed extracellular potential from the patch pipette in voltage-clamp mode. One pipette was used for 3-6 neurons. Each neuron was monitored for $3 \mathrm{~min}$ prior to any treatment in order to determine resting activity. After each control measurement, the dish was treated with CGS, 5-HT, or both. Equilibration times were $30 \mathrm{~min}$ for CGS and 10 min for 5-HT prior to recording. In dishes where both CGS and 5-HT were added, $5-\mathrm{HT}$ was added $30 \mathrm{~min}$ after the CGS, and recordings were taken 10 min later to mimic the protocol used in studies on neurite outgrowth.

Patch-clamp analysis. Tight-seal whole-cell recordings were made from the somata of spherical B 19 neurons that were used within several hours after they were isolated into culture and, hence, did not exhibit any outgrowth. This ensured that an effective space clamp could be achieved. Neurons were visualized at $200 \times$ magnification on an inverted microscope (Nikon) placed on a vibration-free table (Newport). Currents were measured with a patch-clamp amplifier (Dagan) that was under computer control (Indec). All experiments were carried out at room temperature $\left(18-22^{\circ} \mathrm{C}\right)$.

Patch pipettes were made as described above. Pipettes had an average bath resistance of 1-3 M $\Omega$ when filled with patch solution and were not fire polished. The pipette potential was adjusted to give 0 current between the pipette and bath solution immediately before patching onto cells. This ensured that no current was applied to the cell during the patching process. Gentle suction applied to membrane patches resulted in seal resistances of $>1 \mathrm{G} \Omega$ in about $80 \%$ of the trials. After forming the seal, compensation for electrode capacitance was made over 2 different ranges of time constants (fast and medium) using independent circuitry for each range. Next, a brief, more intense suction was applied to break through the cell membrane without disrupting the seal. Access to the cell interior was signaled by the sudden appearance of the wholecell capacitance transient during continuously applied test pulses. Series resistance was compensated electronically and ranged from 1 to $3 \mathrm{M} \Omega$ for most experiments. Membrane current was allowed to stabilize for a few minutes prior to the start of the solution-changing protocol.

Voltage-clamp protocol and analysis of ionic currents were controlled by computer using software designed in the laboratory with BASIC- 23 . Cells were held at $-60 \mathrm{mV}$ and stepped in $10-\mathrm{mV}$ increments to +50 $\mathrm{mV}$ using a series of command voltage pulses generated by an LSI 11/ $23+$ computer. Pulses were $200 \mathrm{msec}$ in duration and spaced $2 \mathrm{sec}$ apart, to ensure that currents from successive pulses did not interact. Current measurements were digitized (sampling frequency, $5 \mathrm{kHz}$ ) and stored for subsequent off-line analysis. Leakage current and cell capacitance were subtracted from current records using digitally scaled, 10$\mathrm{mV}$ hyperpolarizing command pulses (average of 16 traces) given at the beginning of each command-pulse series.

$\mathrm{Ca}^{2+}$ currents were measured under conditions that blocked sodium and potassium currents. Inward sodium currents were eliminated by the use of sodium-free medium (salt-free L-15 medium and the following salts: $0 \mathrm{~mm} \mathrm{NaCl}, 4.1 \mathrm{mM} \mathrm{CaCl}_{2}, 1.5 \mathrm{~mm} \mathrm{MgCl}_{2}, 1.7 \mathrm{mM} \mathrm{KCl}$, and $10 \mathrm{~mm}$ HEPES, adjusted to $\mathrm{pH} 7.4$ with $\mathrm{HCl}$; Haydon and Man-SonHing, 1988) in all experiments. Potassium-channel-blocking agents, 30 mM tetraethylammonium chloride (TEA) and $10 \mathrm{~mm}$ 4-aminopyridine (4-AP), were added to the bathing medium, and $\mathrm{Cs}^{+}$ions were present in the pipette solution in order to block outward potassium currents. The pipette solution contained $35 \mathrm{~mm} \mathrm{CsCl}, 5 \mathrm{~mm} \mathrm{MgCl}_{2}, 5 \mathrm{~mm}$ EGTA, and 5 mM HEPES, adjusted to pH 7.4 with $\mathrm{CsOH}$ (Haydon and ManSon-Hing, 1988). The magnesium salt of adenosine triphosphate (5 $\mathrm{mm}$ ) and the sodium salt of guanosine triphosphate (1 mM) were added to the intracellular patch solution just prior to each patching session to slow any potential rundown of $\mathrm{Ca}^{2+}$ currents. In experiments using $\mathrm{Ca}^{2+}$ channel blockers, addition of $\mathrm{Co}^{2+}(5 \mathrm{~mm})$ to the culture medium required readjustment of the $\mathrm{pH}$.

Solutions were changed by whole-bath perfusion. Solution changes were usually complete within $2-4 \mathrm{~min}$. The dish volume was changed 3 times for each test solution to eliminate residue from previous treatments. This volume was sufficient to reverse the effects of test solutions.
For patch-clamp analysis, CGS was prepared in sodium-free defined medium.

Myosin light chain kinase (MLCK) assay. CGS and other drugs were tested as calmodulin inhibitors by their ability to inhibit CaM activation of smooth muscle MLCK. Myosin light chain $\left(\mathrm{LC}_{20}\right)$ and MLCK were purified from chicken smooth muscle (Edelman et al., 1990). MLCK $(0.05 \mu \mathrm{g} / \mathrm{ml})$ and $\mathrm{LC}_{20}(30 \mu \mathrm{M})$ were incubated at $25^{\circ} \mathrm{C}$ in an assay volume of $40 \mu \mathrm{l}$ with a solution containing $50 \mathrm{~mm}$ Tris buffer $(\mathrm{pH}, 7.6), 0.5 \mathrm{~mm}$ dithiothreitol (DTT), $10 \mathrm{mM} \mathrm{MgCl}_{2}, 0.5 \mathrm{mg} / \mathrm{ml} \mathrm{BSA}, 0.5 \mathrm{mM} \mathrm{CaCl}$, and $0.4 \mathrm{mM}\left(\gamma-{ }^{32} \mathrm{P}\right) \mathrm{ATP}\left(1.6-5.1 \times 10^{6} \mathrm{cpm}\right.$; New England Nuclear/ DuPont). The concentration of $\mathrm{CaM}$ in the assay was approximately equal to its $K_{0.5}$ for activation of MLCK. CaM was supplied as that endogenously present in the $\mathrm{LC}_{20}$ preparation. The phosphorylation reactions were stopped at 7 and 14 min by pipetting $15-\mu 1$ aliquots of the reaction mixtures onto $3 \mathrm{MM}$ (Whatman) filter paper squares and placing these in a $10 \%$ ice-cold trichloracetic acid (TCA) wash. Following a 15-min wash in the cold TCA, 3 subsequent wshes were done: 1 in $10 \%$ TCA at room temperature $(30 \mathrm{~min})$ and 2 in $5 \% \mathrm{TCA}$ at room temperature for $15 \mathrm{~min}$ each. The squares were then rinsed in $95 \%$ ethanol, dried, and subjected to liquid scintillation spectrometry. Results, expressed as moles of ${ }^{32} \mathrm{P}$ incorporated per mole of $\mathrm{LC}_{20}$ plotted as a function of drug concentration, were used to determine $\mathrm{IC}_{50}$ values for CGS and TFP.

Preparation of CaM antagonists. CGS was synthesized and analyzed as described previously (Norman et al., 1987). CGS was found to be less soluble in the physiological media used for measuring neuronal growth and ionic currents than in the MLCK assay. For this reason, a standard curve of the concentration-dependent inhibition of MLCK by CGS was constructed. Concentrations of CGS in stock solutions in media were quantitated after removal of insoluble material using this standard curve. Stock solutions of TFP and W-7 were made in distilled water and $95 \%$ ethanol, respectively.

Statistical analysis. Where appropriate, data are given as the mean \pm SEM. Statistical analysis was performed using the Student's $t$ test for matched or unmatched samples, as appropriate.

\section{Results}

\section{Effect of CGS on 5-HT-induced suppression of neurite outgrowth}

Actively growing B19 neurons were studied to determine the effects of 5-HT and CGS on growth cone movements and neurite outgrowth. As shown in Figure 1, the addition of $100 \mu \mathrm{M}$ 5-HT to isolated B 19 neurons caused a dramatic decrease in the rate of neurite elongation compared to the baseline period. In contrast, pretreatment with CGS $(1.8 \mu \mathrm{M})$ completely blocked thc 5-HT-induced suppression of neurite elongation. In the presence of CGS and 5-HT, the rate of elongation was not significantly different from CGS-alone-treated baseline rates.

The ability of CGS to block the suppression of neurite elongation induced by 5 -HT was dose dependent over a CGS concentration range of 0.09-3.6 $\mu \mathrm{M}$ (Fig. 2). This effect was maximal at $1.8 \mu \mathrm{M}$ and half-maximal at approximately $1.4 \mu \mathrm{M}$. In the presence of 5-HT, $1.8 \mu \mathrm{M}$ CGS produced a small $(\sim 30 \%)$ but significant increase in elongation rate relative to the baseline period, though this was not observed at $3.6 \mu \mathrm{M}$ CGS. CGS alone $(0.9-1.8 \mu \mathrm{M})$ caused a small $(25-30 \%)$ but significant $(p<0.005)$ decrease in elongation rate compared to the untreated baseline period. The concentration of CGS required to block 5-HT effects on neurite outgrowth was similar to that required to block CaM activation of the CaM-dependent enzymes MLCK (Table 1) and phosphodiesterase (Norman et al., 1987).

The decreased elongation rates in the presence of 5-HT were accompanied by morphological changes in the growth cone (Haydon et al., 1984). Motile growth cones were normally flat, broad, phase-dark structures. After the addition of $100 \mu \mathrm{M} 5-\mathrm{HT}$, they became narrow, club shaped, and phase bright, retracted their lamellipodia, and lost their filopodia (Fig. $3 A, B$ ). When 


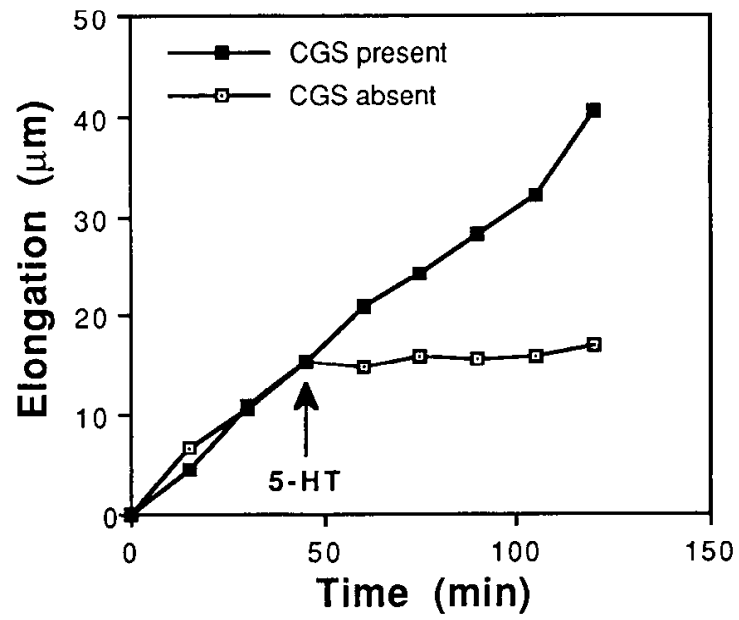

Figure 1. Block by CGS of 5-HT-induced suppression of neurite outgrowth. 5-HT $(100 \mu \mathrm{M})$ was applied after $45 \mathrm{~min}$ (arrow) to B 19 neurons cultured either in the presence (solid squares) or absence (open squares) of $1.8 \mu \mathrm{m}$ CGS. When CGS was present, it was added just before the 0 time point and remained in the culture for the entire 2 -hr measurement period. Representative traces from 2 B 19 growth cones are shown.

CGS alone (0.9-1.8 $\mu \mathrm{M})$ was applied to growing B19 neurons in the absence of 5-HT, there was no change in the morphology of the growth cone (not shown), though elongation rates decreased slightly compared to the baseline period, as mentioned above. Pretreatment with $1.8 \mu \mathrm{M}$ CGS prevented the morphological changes induced by $5-\mathrm{HT}$ (Fig. $3 C, D$ ). In the presence of both CGS and 5-HT, growth cones retained their broad lamellipodia and numerous filopodia. A small percentage (30\%) of growth cones exhibited some change in morphology under these conditions; however, these changes were never as pronounced as those that occurred with 5-HT alone. Lower concentrations of CGS $(0.09-0.9 \mu \mathrm{M})$, which only slightly blocked the 5-HT effects on neurite outgrowth, did not reverse 5-HTinduced changes in growth cone morphology. In the presence of 5-HT, the highest-tested concentration of CGS $(3.6 \mu \mathrm{M})$ was also associated with some change in morphology, including loss of some filopodia and partial retraction of lamellipodia in about $57 \%$ of the growth cones (not shown).
Table 1. Anti-CaM activity of CGS and TFP

\begin{tabular}{lc} 
CaM inhibitor & $\mathrm{IC}_{50}$ \\
\hline CGS & $2.7 \mu \mathrm{M}$ \\
TFP & $21 \mu \mathrm{M}$
\end{tabular}

Anti-CaM activity was evaluated by the half-maximal concentration $\left(\mathrm{IC}_{50}\right)$ required to block CaM-dependent activation of MLCK, as described in Materials and Methods.

In addition to the effects on neurite elongation rates and growth cone morphology, we tested the effects of 5-HT and CGS on the extent of neurite outgrowth. The extent of neurite outgrowth was measured as the change in the maximal extent of neurite length $24 \mathrm{hr}$ after the addition of 5-HT. Neurite outgrowth measured on 11 untreated control neurons was $234 \pm 25.4 \mu \mathrm{m}$ and defined as $100 \%$ outgrowth. The application of $0.9-1.8 \mu \mathrm{M}$ CGS alone had no effect on the extent of outgrowth, as compared with untreated control neurons (not shown). The application of 5-HT alone $(100 \mu \mathrm{M})$ caused a $68.5 \%$ decrease in the extent of outgrowth $(73.5 \pm 19.8 \mu \mathrm{m} ; N=11 ; p<0.001)$, as shown in Figure $4 A$. However, when $1.8 \mu \mathrm{M}$ CGS was present in the culture medium prior to the addition of $5-\mathrm{HT}$, the extent of outgrowth was not significantly different from untreated control outgrowth. The 5-HT-induced suppression of outgrowth was blocked by CGS in a dose-dependent fashion (Fig. 4B). This effect was maximal at a CGS concentration of $1.8 \mu \mathrm{M}$. At this concentration, the extent of outgrowth was significantly increased $(199 \pm 30.5 \mu \mathrm{m} ; N=10 ; p<0.001)$ relative to $5-\mathrm{HT}$ alone and was not significantly different from the untreated controls. At a higher concentration of CGS $(3.6 \mu \mathrm{M})$, there was a $45.4 \%$ decrease in the extent of outgrowth compared to untreated controls $(N=20 ; p<0.001)$, and outgrowth was not significantly increased relative to 5 -HT alone. This may indicate a potential nonspecific effect of CGS at higher concentrations (3.6 $\mu \mathrm{M}$ or above) during long-term applications, as this was not observed in shorter-duration studies of elongation rates (see Fig. 2).

\section{Effect of CGS and 5-HT on electrical activity of neurons}

Cultured B19 neurons normally exhibit a low level of spontaneous electrical activity (12.0 spikes/min; Cohan and Kater,

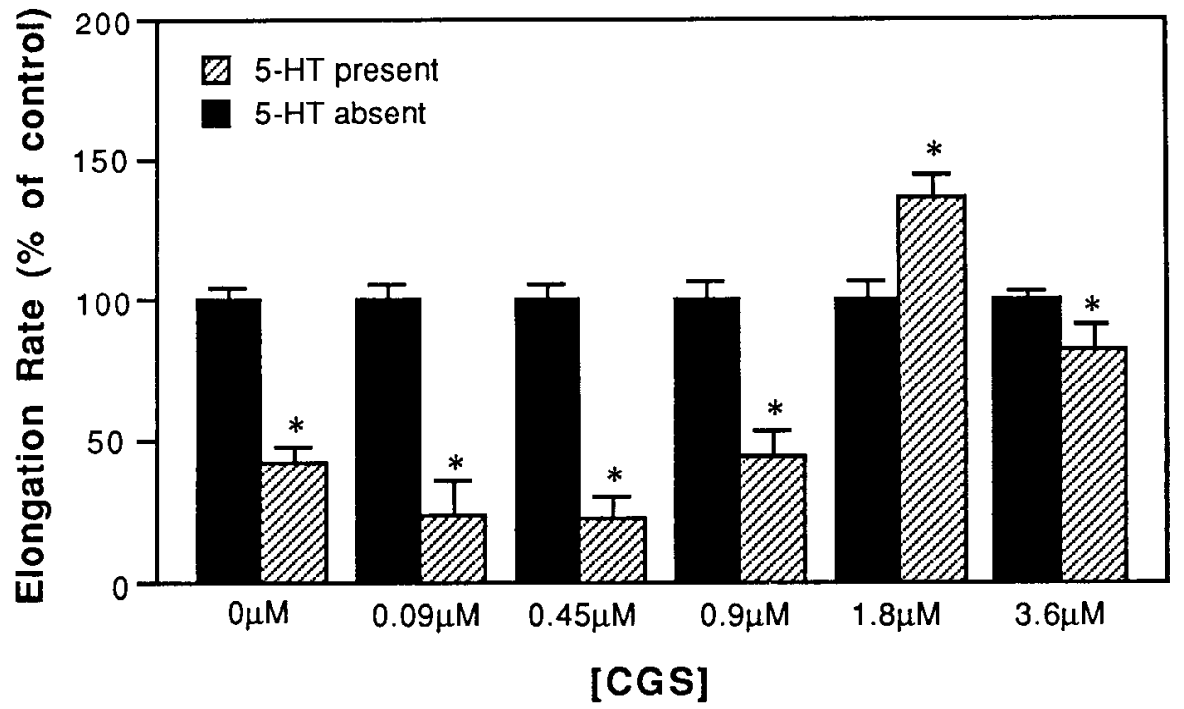

[CGS]
Figure 2. Dose-response relationship of CGS block of 5-HT-induced suppression of neurite elongation. Bars represent elongation rates measured in the absence (solid bars) or presence (hatched bars) of $100 \mu \mathrm{M} 5$-HT and the indicated concentrations of CGS. Each bar represents the mean of 30-64 separate growth cone measurements \pm SEM. Significance level compared to baseline period: ${ }^{*}, p<0.001$. 

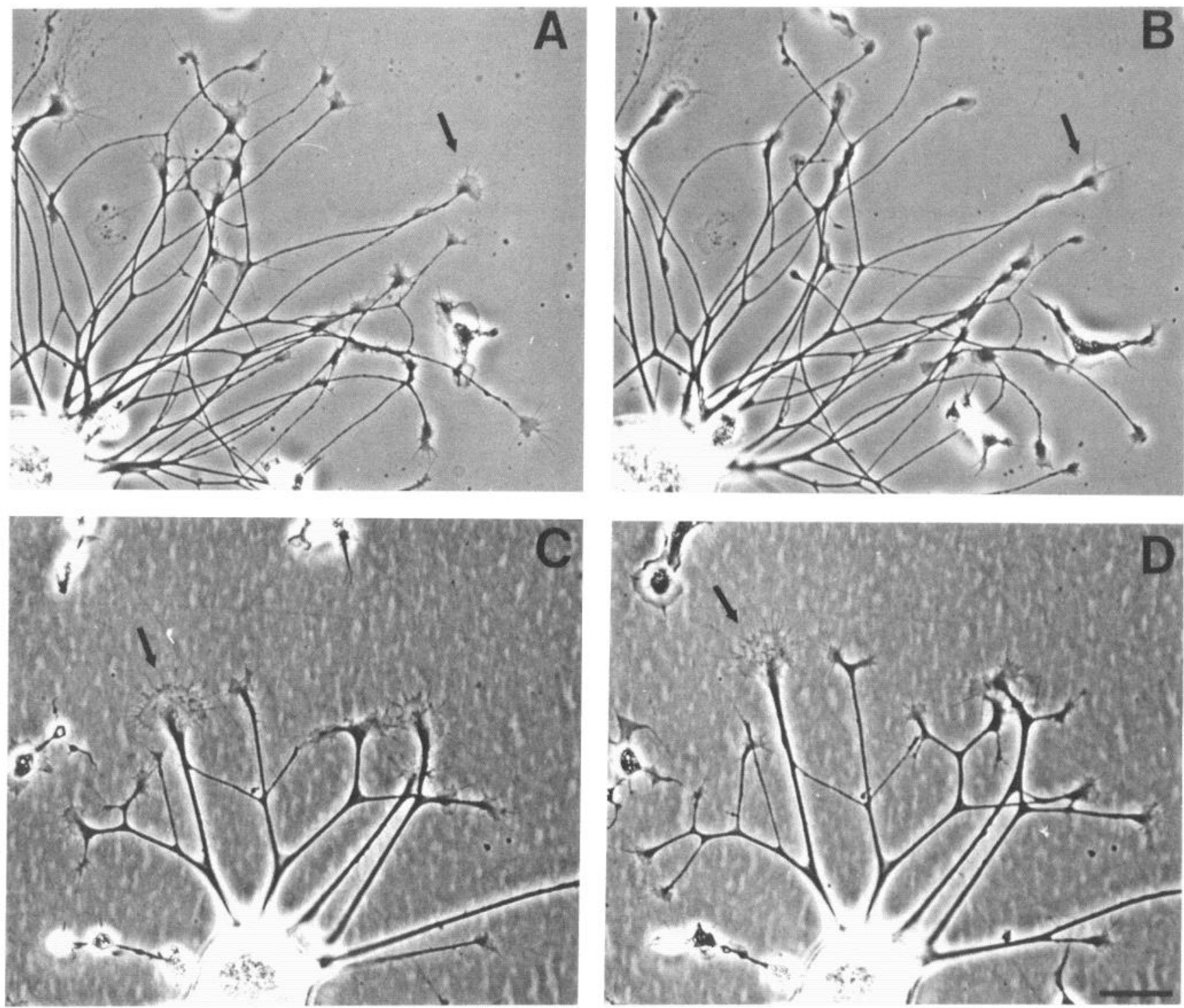

Figure 3. Effects of 5-HT on B19 growth cone morphology in absence or presence of CGS. A, Growth cones of untreated B19 neuron viewed with phase-contrast optics. Note the broad lamellipodia and numerous filopodia on growth cones (arrow). $B$, Growth cone morphology of neuron shown in $A$ after $60 \mathrm{~min}$ in the presence of $100 \mu \mathrm{M}$ 5-HT. Note the lamellipodial retraction and decrease in number of filopodia (compare growth cones at arrows). $C$, Growth cones of B19 neuron in the presence of $1.8 \mu \mathrm{M}$ CGS. $D$, Growth cone morphology of neuron shown in $C$ after an additional $60 \mathrm{~min}$ in the presence of $100 \mu \mathrm{M} 5-\mathrm{HT}$. Note that lamellipodia and filopodia are unchanged by the 5-HT when it is applied in the presence of CGS. Compare growth cones indicated by arrows. Scale bar, $40 \mu \mathrm{m}$.

1986). Previous investigations have shown that 5-HT causes its effects on neurite outgrowth by depolarizing B19, thereby increasing B19 spike frequency (McCobb et al., 1988a). As shown in Figure 5, 5-HT $(100 \mu \mathrm{M})$ caused an 8-fold increase in the electrical activity of B19 neurons $(p<0.001)$. When 5 -HT was applied in the presence of $1.8 \mu \mathrm{M}$ CGS, there was also a large (5-fold) increase in electrical activity $(p<0.001)$. The application of $1.8 \mu \mathrm{M}$ CGS alone had no significant effect on electrical activity of B19 neurons $(70.5 \pm 20.6$ spikes/min for controls vs. $50 \pm 19.6 \mathrm{spikes} / \mathrm{min}$ for CGS-treated cells; $N=6$ ). These results indicate that 5-HT depolarizes B19 neurons in either the presence or the absence of CGS.

\section{Effects of CaM antagonists on $\mathrm{Ca}^{2+}$ currents}

$\mathrm{Ca}^{2+}$ currents were measured in cultured B19 neurons, within $2 \mathrm{hr}$ of isolation, to determine whether CGS had any direct effects on $\mathrm{Ca}^{2+}$ entry across the neuronal membrane. Other $\mathrm{CaM}$ inhibitors (W-7, TFP) have been shown to antagonize membrane $\mathrm{Ca}^{2+}$ currents in other systems, in addition to their $\mathrm{CaM}$ inhibitory activity (Doroshenko et al., 1988; Safayhi et al., 1989). The acutely isolated somata of $\mathrm{B} 19$ were voltage clamped before any outgrowth had begun, to ensure adequate voltage control of the cell. Inward currents were activated at -30 to $-20 \mathrm{mV}$, reached peak values at around $+20 \mathrm{mV}$, and reversed at +40 to $+60 \mathrm{mV}$. These reversal potentials span the range of reversals for $\mathrm{Ca}^{2+}$ currents in a variety of vertebrate and invertebrate neuronal preparations. Two types of $\mathrm{Ca}^{2+}$ currents have been characterized in Helisoma neurons: the low-voltage-activated (LVA) and high-voltage-activated (HVA) currents (Haydon and Man-Son-Hing, 1988). LVA currents were observed in approximately $30 \%$ of the cells tested. LVA current was activated during depolarizing commands to $-50 \mathrm{mV}$ and $-40 \mathrm{mV}$ from a 

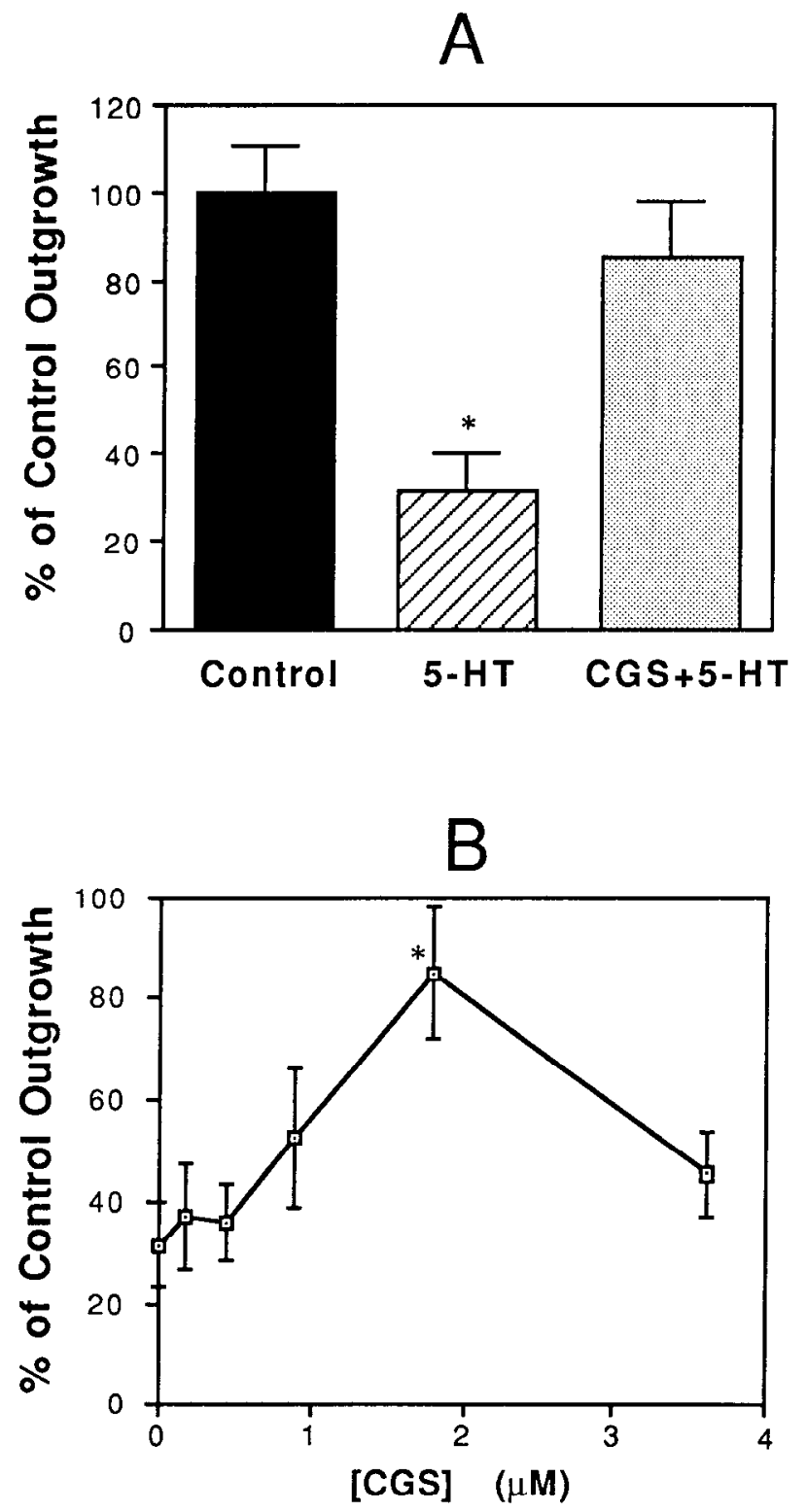

Figure 4. Effect of 5-HT and CGS on extent of neurite outgrowth of B19 neurons. $A$, Extent of outgrowth was measured for untreated control neurons (solid bar) and for neurons in the presence of $100 \mu \mathrm{M} 5-\mathrm{HT}$ (hatched bar) and $100 \mu \mathrm{M} 5-\mathrm{HT}$ in the presence of $1.8 \mu \mathrm{M}$ CGS (stippled bar). Extent of outgrowth is expressed as the percentage of untreated control outgrowth (mean $\pm \mathrm{SEM} ; N=10-11$ neurons). Significance level compared to control: ${ }^{*}, p<0.001, B$, Dose-response relationship of the block of 5-HT-induced suppression of extent of outgrowth. Note that 0 on the abscissa indicates the effect of 5-HT alone. Significance level compared to $100 \mu \mathrm{M}$ 5-IIT: ${ }^{*}, p<0.001$.

holding potential of $-60 \mathrm{mV}$. Peak $\mathrm{Ca}^{2+}$ currents in $\mathrm{B} 19$ cell bodies ranged from 1.75 to $>5.0 \mathrm{nA}$. Rundown of current was negligible over a 30-45-min period observed for control neurons (not shown). Representative current traces and corresponding current-voltage plots are shown in Figures 6-8. Addition of 200

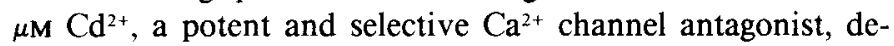
creased inward currents by $78 \%$ relative to control levels ( $p<$ 0.001 ) within $2 \mathrm{~min}$ of application (Fig. 6). Removal of $\mathrm{Cd}^{2+}$ from the bathing medium restored currents to control levels within $5 \mathrm{~min}$. The addition of $5 \mathrm{~mm} \mathrm{Co}^{2+}$ also produced a

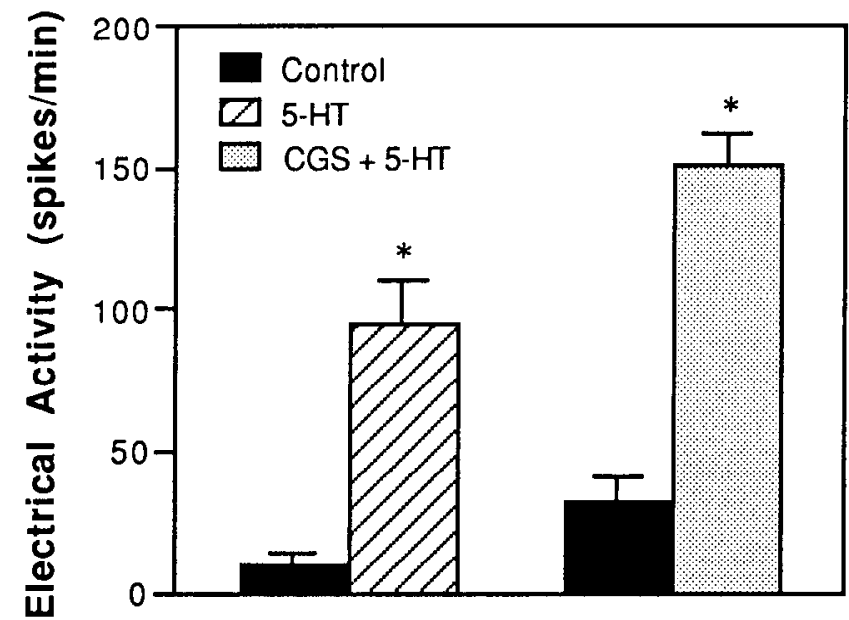

Figure 5. Effects of 5-HT and CGS on electrical activity of cultured B19 neurons. Bars represent mean spike frequencies \pm SEM $(N=6-$ 12 neurons) recorded extracellularly from untreated controls (solid bar) or after the application of $100 \mu \mathrm{M} 5$-HT (hatched bar) or $100 \mu \mathrm{M}$ 5-HT in the presence of $1.8 \mu \mathrm{M}$ CGS (stippled bar). Significance level compared to untreated controls: ${ }^{*}, p<0.001$.

significant $(p<0.001)$, reversible block of inward current within $5 \mathrm{~min}$ of application (not shown).

We then tested the effects of TFP and $\mathrm{W}-7$ on $\mathrm{Ca}^{2+}$ currents. TFP at a concentration $(35 \mu \mathrm{M})$ similar to its $\mathrm{IC}_{50}$ for $\mathrm{CaM}$ inhibition (Table 1 ) reversibly reduced inward $\mathrm{Ca}^{2+}$ currents by about $57 \%(p<0.001)$ within $5 \mathrm{~min}$ of application (Fig. $7 A, B)$. Both LVA and HVA currents were reduced by TFP. Upon removal of TFP, currents recovered to control levels within 15$20 \mathrm{~min}$. Similar effects were observed with $100 \mu \mathrm{M} \mathrm{W-7} \mathrm{(not}$ shown). Thus, these nonselective CaM antagonists also function as $\mathrm{Ca}^{2+}$ channel antagonists in Helisoma neuron B19.

By contrast, CGS produced no significant decreases in $\mathrm{Ca}^{2+}$ current over the 20-min period of study (Fig. 8). Records of $\mathrm{Ca}^{2+}$ current are shown for $1.8 \mu \mathrm{M}$ CGS, the concentration that produced maximal block of 5-HT-induced effects on neurite elongation rates, extent of outgrowth, and growth cone morphology. In B19 cell bodies that exhibited an LVA current, the magnitude of neither the LVA nor the HVA current was significantly affected by CGS. A quantitative comparison of the effects of $\mathrm{CaM}$ blockers on $\mathrm{Ca}^{2+}$ currents in voltage-clamped B19 neurons is shown in Figure 9. Currents are expressed as a percentage of the control current record taken prior to treatment of each cell. Decreases in current occurred within $10 \mathrm{~min}$ of application of TFP, W-7, and $\mathrm{Cd}^{2+}$, but were not observed over $20 \mathrm{~min}$ of exposure to $0.9-3.6 \mu \mathrm{M}$ CGS. Our results demonstrate that CGS does not act as a $\mathrm{Ca}^{2+}$ channel antagonist in $\mathrm{B} 19$ at concentrations that block $\mathrm{CaM}$ activity (Table 1) and $\mathrm{Ca}^{2+}$ dependent 5-HT effects on neuronal outgrowth and morphology (Figs. 1-5).

\section{Discussion}

The rate and extent of neurite outgrowth are now known to be responsive to a variety of stimuli, including neurotransmitters and electrical activity (Haydon et al., 1984). Accumulated evidence suggests that these effects are mediated intracellularly by $\mathrm{Ca}^{2+}$. We utilized the potent, selective CaM inhibitor CGS 9343B (Norman et al., 1987) to investigate the possible mediation by $\mathrm{CaM}$ of $\mathrm{Ca}^{2+}$-induced changes in neurite outgrowth. Our findings 


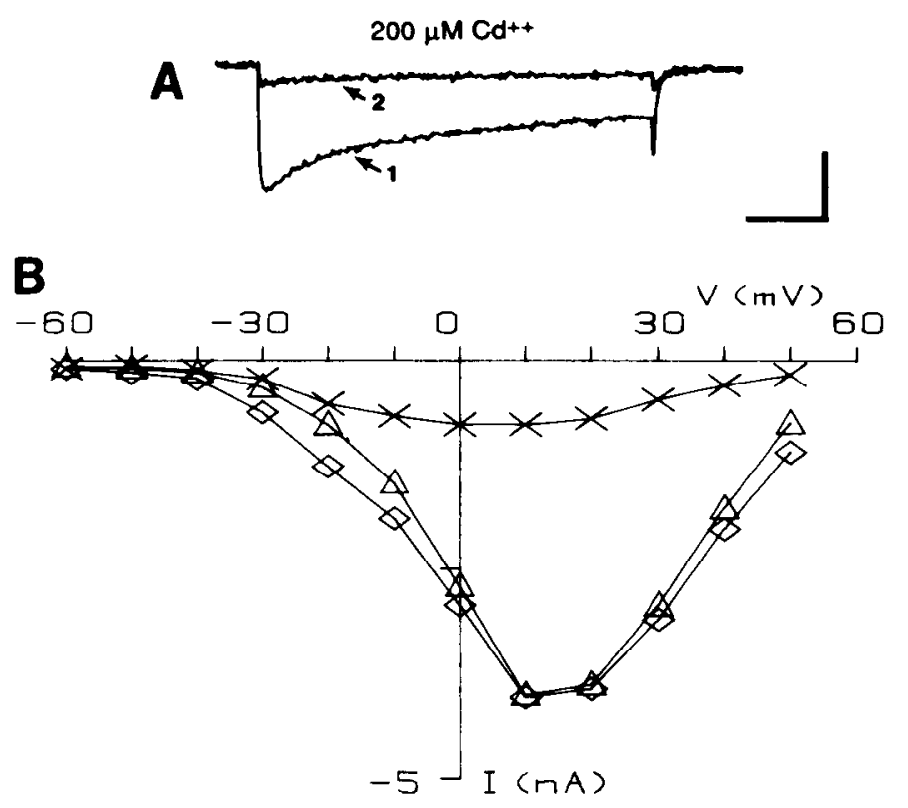

Figure 6. Effect of $\mathrm{Cd}^{2+}$ on inward $\mathrm{Ca}^{2+}$ currents in acutely isolated somata of B19 neurons. $A$, Representative traces of inward membrane current (downward direction) in voltage-clamped B19 somata held at $-60 \mathrm{mV}$ and stepped to $+20 \mathrm{mV}$ by a command pulse. Membrane current was measured prior to the addition of $200 \mu \mathrm{M} \mathrm{Cd}^{2+}(I)$ and then 2 min after its addition to the bath (2). $B$, The corresponding $I / V$ plot for the same neuron. Points indicate peak inward currents recorded before $(\triangle), 2 \mathrm{~min}$ after addition of $200 \mu \mathrm{M} \mathrm{Cd}^{2+}(\mathrm{x})$, and then after washout of the $\mathrm{Cd}^{2+}(0)$. Calibration: $2 \mathrm{nA}, 40 \mathrm{msec}$.

show that CGS blocked the 5-HT-induced suppression of both rate and total extent of neurite outgrowth, as well as the attendant morphological changes. The effects of CGS were dose dependent and occurred in a concentration range (0.9-3.6 $\mu \mathrm{M})$ similar to its ability to inhibit CaM activation of CaM-dependent enzymes $\left(\mathrm{IC}_{50}, \sim 3 \mu \mathrm{M}\right)$.

The application of CGS alone to B19 neurons caused a slight decrease in the rate of neurite elongation. Perhaps CGS itself has a small inhibitory effect on neurite elongation. However, this effect may be transient, as there was no difference in the extent of neurite outgrowth of neurons treated with CGS alone compared to untreated controls. These small (presumably nonspecific) effects of CGS on growth rate suggest that CaM may play a role in the mechanism of transmitter-induced suppression of neurite outgrowth rather than in the more general process of neurite outgrowth per se.

CGS not only suppressed the effects of 5-HT on neurite elongation, but it also resulted in an enhanced rate of outgrowth at a concentration of $1.8 \mu \mathrm{M}$ (Fig. 2). This increased rate of growth suggests that neurite elongation can be upregulated as well as downregulated by appropriate stimuli. Enhanced rates of outgrowth have also been observed in response to electrical stimulation of Helisoma neurons. Stimulation of action potentials in outgrowing B4 neurons at specific frequencies results in a poststimulation enhancement of growth cone movement (Cohan, 1990). However, the stimulation frequencies that enhanced growth rates of B4 did not result in a significant increase in growth rates of B19. The present experiments indicate that both enhancement as well as depression of growth rate may be a general property of growth cones that can occur under appropriate conditions.
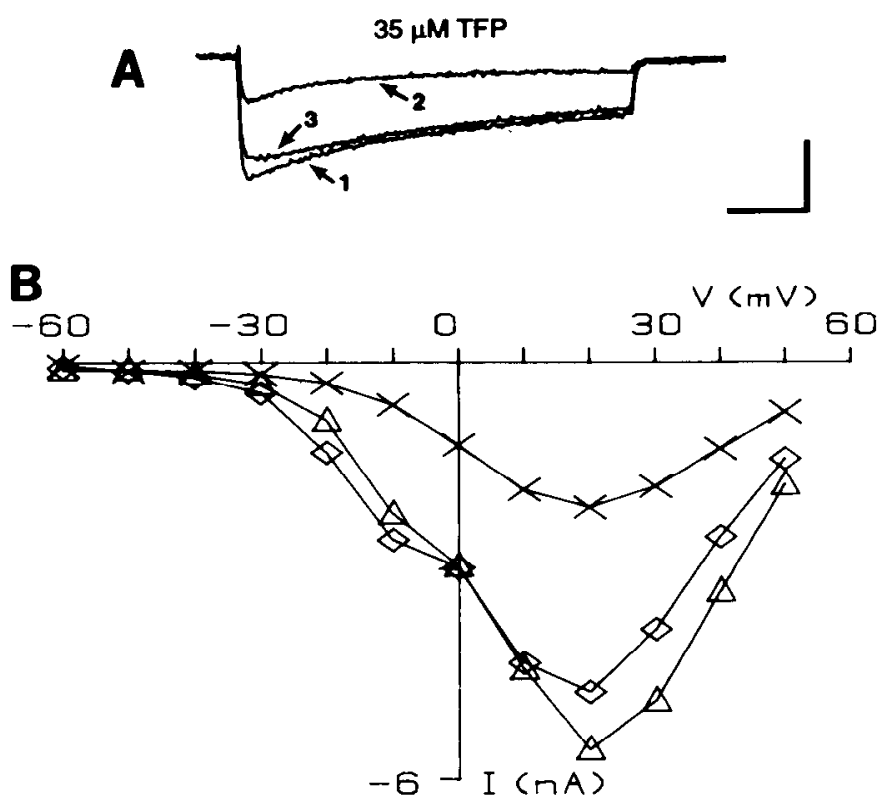

Figure 7. Effect of TFP on inward $\mathrm{Ca}^{2+}$ currents in acutely isolated B19 somata. $A$, Representative traces of membrane current in voltageclamped B 19 somata held at $-60 \mathrm{mV}$ and stepped to $+20 \mathrm{mV}$. Membrane current was measured prior to the addition of $35 \mu \mathrm{M}$ TFP $(1), 5$ min after TFP addition (2), and after washout of TFP from the bathing solution (3). $B$, The corresponding $I / V$ plot for the same neuron. Points indicate peak inward currents recorded before TFP $(\triangle), 5 \mathrm{~min}$ after addition of TFP $(x)$, and then after washout $(\diamond)$. Note the presence of both an LVA and an HVA Ca ${ }^{2+}$ current in this neuron, as indicated by the characteristic plateau in the current-voltage relationship. Calibration: $3 \mathrm{nA}, 40 \mathrm{msec}$.
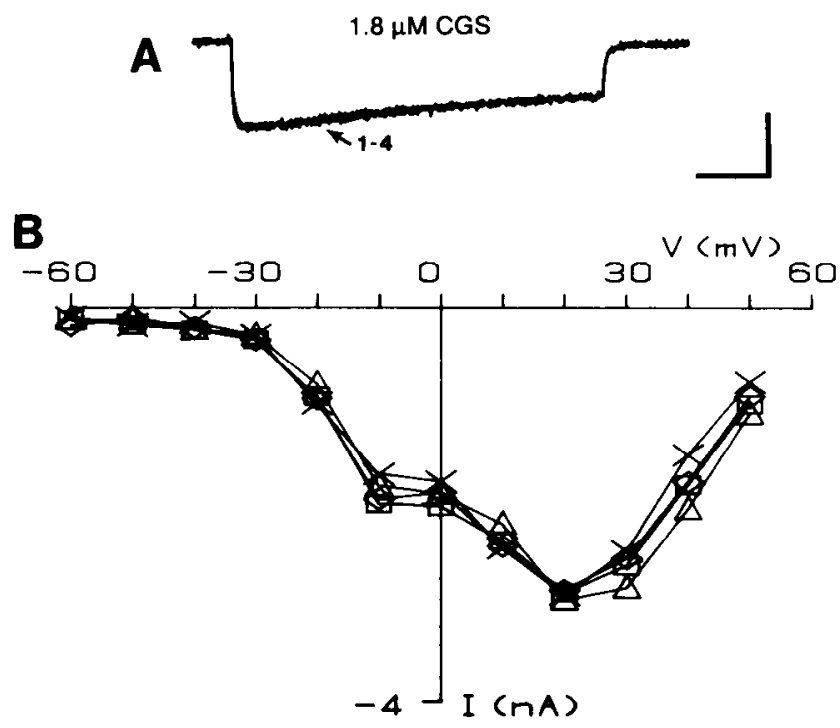

Figure 8. Inward $\mathrm{Ca}^{2+}$ currents in acutely isolated $\mathrm{B} 19$ somata in absence and presence of CGS. $A$, Representative traces of membrane current in voltage-clamped $\mathrm{B} 19$ somata held at $-60 \mathrm{mV}$ and stepped to $+20 \mathrm{mV}$. Membrane current was measured prior to the addition of 1.8 $\mu \mathrm{M}$ CGS (l) and then $2 \mathrm{~min}(2), 10 \mathrm{~min}(3)$, and $20 \mathrm{~min}(4)$ after its addition to the bath. All traces superimpose, indicating no change in the membrane current with time. $B$. The corresponding $I / V$ plot for the same neuron. Points indicate peak inward currents recorded before $(\triangle)$, and then $2 \mathrm{~min}(\mathrm{x}), 10 \mathrm{~min}(\diamond)$, and $20 \mathrm{~min}(\square)$ after addition of 1.8 $\mu \mathrm{M}$ CGS to the medium. Note that this neuron also displays both an LVA and an HVA Ca ${ }^{2+}$ current and that neither are affected by the CGS. Calibration: 2 nA, 40 msec. 


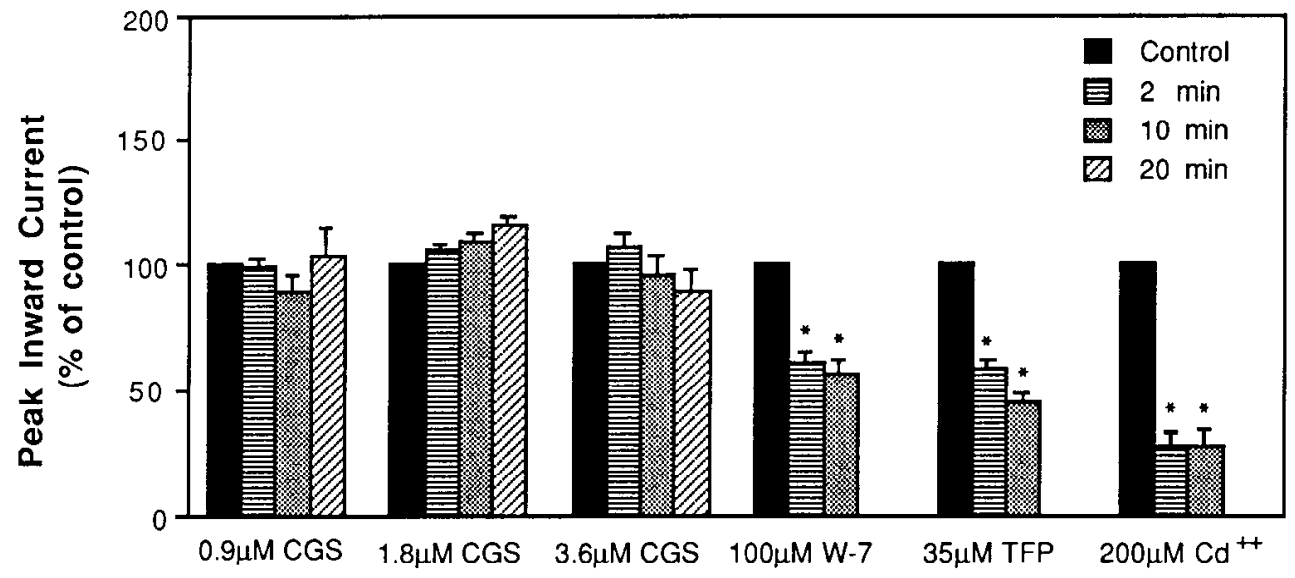

Figure 9. Quantitation of changes in $\mathrm{Ca}^{2+}$ currents in acutely isolated B19 somata exposed to $\mathrm{Cd}^{2+}$, TFP, W-7, or CGS. All neurons were held at $-60 \mathrm{mV}$ and stepped to $+20 \mathrm{mV}$ by a command pulse. Control current measurements were taken for each neuron prior to treatment. Peak inward current after treatment is expressed as a percentage of the control peak inward current (mean $\pm \mathrm{SEM} ; N=9-14$ neurons at each concentration). Significance level compared to controls: ${ }^{*}, p<0.001$
We considered 2 alternative explanations for the mechanism of CGS action. Reversal of 5-HT-induced suppression of neurite outgrowth would also occur if CGS was acting as a 5-HT receptor antagonist. The ability of 5-HT to depolarize B19 neurons was not blocked by the presence of CGS in the medium (Fig. 5), indicating that CGS was not acting as a 5-HT receptor antagonist.

A second alternative would be if CGS was acting as a $\mathrm{Ca}^{2+}$ channel antagonist. Previously studied CaM antagonists, such as W-7 and TFP, have been shown to block voltage-sensitive $\mathrm{Ca}^{2+}$ channels in snail neurons (Doroshenko et al., 1988), embryonic chick heart cells (Bkaily et al., 1984), bovine chromaffin cells (Clapham and Neher, 1984), rat insulinoma cells (Safayhi et al., 1989), and Paramecium (IIennessey and Kung, 1984). However, unlike W-7 and TFP, CGS did not after $\mathrm{Ca}^{2+}$ currents in neuron $\mathrm{B} 19$, even at concentrations greater than those required to block the effects of 5-HT on neurite outgrowth (Figs. 7-9). The application of CGS to the culture medium, at concentrations up to $3.6 \mu \mathrm{M}$, did not reduce either LVA or HVA $\mathrm{Ca}^{2+}$ currents over the 20-min observation period. The lack of effect of CGS on $\mathrm{Ca}^{2+}$ currents may be cell-type specific, as it was reported that $\mathrm{CGS}$ blocked $\mathrm{Ca}^{2+}$ changes induced by alanine or potassium depolarization in rat insulinoma cells, measured using Quin-2 (Safayhi et al., 1989). Therefore, because CGS does not block either the 5-HT receptor or voltage-sensitive $\mathrm{Ca}^{2+}$ channels in $\mathrm{B} 19$, its ability to reverse the effects of 5-HT may be due directly to its antagonism of CaM activity.

One possible mechanism whereby CaM may mediate $\mathrm{Ca}^{2+}$ dependent regulation of neurite elongation and growth cone motility is through the activation of specific regulatory enzymes within the growth cone. CaM is present in all eukaryotic cells that have been examined (Means et al., 1982; Manalan and Klee, 1984), and both CaM and a series of high-affinity CaMbinding proteins are found in growth cones from the fetal rat brain (Hyman and Pfenninger, 1985). CaM is known to confer $\mathrm{Ca}^{2+}$ sensitivity on numerous enzymes, including adenylate cyclase, cyclic nucleotide phosphodiesterase, $\mathrm{Ca}^{2+} / \mathrm{Mg}^{2+}$-ATPase, MLCK, and calcineurin, a protein phosphatase (Manalan and Klee, 1984).

One enzyme that may play a pivotal role in CaM-mediated processes in growth cones is type II $\mathrm{Ca}^{2+} / \mathrm{CaM}$-dependent protein kinase (CaM kinase II). CaM kinase II is the predominant $\mathrm{Ca}^{2+} / \mathrm{CaM}$-dependent protein kinase in neuronal tissue and comprises about $1 \%$ of the total brain protein (Kennedy et al., 1987). CaM kinase II has a relatively broad substrate specificity and phosphorylates a variety of neuronal cytoskeletal proteins, including $\alpha$ and $\beta$ tubulin (Goldenring et al., 1983; Yamamoto et al., 1985), MAP-2 (Yamauchi and Fujisawa, 1982; Schulman, 1984), and synapsin I (Kennedy and Greengard, 1981). In addition, phosphorylation of MAP-2 by CaM kinase II causes a decrease in the rate of microtubule assembly and also promotes microtubule disassembly (Yamamoto et al., 1983; Yamauchi and Fujisawa, 1983). Furthermore, phosphorylation of MAP-2 by CaM kinase II inhibits the actin filament cross-linking activity of MAP-2 (Yamauchi and Fujisawa, 1988). These interactions may also be important in mediating the effects of $\mathrm{Ca}^{2+}$ changes on neurite outgrowth. Because the structural basis of motility in many cells must involve the cytoskeleton, the $\mathrm{Ca}^{2+}$ $\mathrm{CaM}$ complex could also regulate neurite outgrowth and growth cone movements through the activation or deactivation of as yet unidentified regulatory structural proteins.

In addition to its lack of effects on mouse brain PKC, calf brain dopamine receptors (Norman et al., 1987), 5-HT receptors, and voltage-activated $\mathrm{Ca}^{2+}$ channels in Helisoma $\mathrm{B} 19$ neurons (Figs. 5, 8, 9), CGS has been reported not to affect cAMP-dependent protein kinase activity, passive $\mathrm{Ca}^{2+}$ flux, and ATP-dependent $\mathrm{Ca}^{2+}$ uptake in rat liver epithelial cells (Hill et al., 1988). However, it is still conceivable that CGS may interact with a non-CaM protein involved in neurite outgrowth. Nevertheless, the selectivity, as well as the potency, of CaM inhibition by CGS, as evidenced by its ability to antagonize 5-HT effects on outgrowth without altering membrane depolarization or $\mathrm{Ca}^{2+}$ currents, suggest that $\mathrm{CaM}$ is involved in mediating some of the effects of increased $\mathrm{Ca}^{2+}$ on growth cone motility and neurite outgrowth in cultured B19 neurons.

\section{References}

Bkaily G, Sperelakis N, Elderfrawi M (1984) Effects of the calmodulin inhibitor, trifluoperazine, on membrane potentials and slow action potentials of cultured heart cells. Eur J Pharmacol 105:23-31.

Clapham DE, Neher E (1984) Trifluoperazine reduces inward ionic currents and secretion by separate mechanisms in bovine chromaffin cells. J Physiol (Lond) 353:541-564.

Cohan CS (1990) Frequency-dependent and cell-specific effects of electrical activity on growth cone movements of cultured Helisoma neurons. J Neurobiol 21:400-413.

Cohan CS, Kater SB (1986) Suppression of neurite elongation and growth cone motility by electrical activity. Science 232:1638-1640.

Cohan CS, Connor JA, Kater SB (1987) Electrically and chemically mediated increases in intracellular calcium in neuronal growth cones. J Neurosci 7:3588-3599.

Doroshenko PA, Kostyik PG, Luk'yanetz EA (1988) Modulation of 
calcium current by calmodulin antagonists. Neuroscience 27:10731080.

Edelman AM, Lin W-H, Osterhout DJ, Bennett MK, Kennedy MB, Krebs EG (1990) Phosphorylation of smooth muscle myosin by type II Ca ${ }^{2+} /$ calmodulin-dependent protein kinase. Mol Cell Biochem 97:87-98.

Goldenring JR, Gonzalez B, McCiuire JS, DeLorenzo RJ (1983) Purification and characterization of a calmodulin-dependent kinase from rat brain cytosol able to phosphorylate tubulin and microtubule-associated proteins. J Biol Chem 258:12632-12640.

Greenberg DA, Carpenter CL, Messing RO (1987) Interaction of calmodulin inhibitors and protein kinase $C$ inhibitors with voltage-dependent calcium channels. Brain Res 404:401-404.

Haydon PG, Man-Son-Hing H (1988) Low- and high-voltage-activated calcium currents: their relationship to the site of neurotransmitter release in an identified neuron of Helisoma. Neuron 1:919927.

Haydon PG, McCobb DP, Kater SB (1984) Serotonin selectivity inhibits growth cone motility and synaptogenesis of specific identified neurons. Science 226:561-564.

Hennessey TM, Kung C (1984) An anticalmodulin drug, W-7, inhibits the voltage-dependent calcium current in Paramecium caudatum. $\mathbf{J}$ Exp Biol 110:169-181.

Hill TD, Campos-Gonzales R, Kindmark H, Boynton AL (1988) Inhibition of inositol trisphosphate-stimulated calcium mobilization by calmodulin antagonists in rat liver epithelial cells. J Biol Chem 263: 16479-16484

Hyman C, Pfenninger KH (1985) Intracellular regulators of neuronal sprouting: calmodulin-binding proteins of nerve growth cones. $J$ Cell Biol 101:1153-1160.

Job D, Fischer EH, Margolis R (1981) Rapid disassembly of coldstable microtubules by calmodulin. Proc Natl Acad Sci USA 78:46794682 .

Kater SB, Kaneko CRS (1972) An endogenously bursting neuron in the gastropod mollusc Helisoma trivolvis: characterization of activity in vivo. J Comp Physiol 79:1-14.

Kennedy MB, Greengard P (1981) Two calcium/calmodulin-dependent protein kinases, which are highly concentrated in brain, phosphorylate protein I at distinct sites. Proc Natl Acad Sci USA 78:12931297.

Kennedy MB, Bennett MK, Erondu NE, Miller SG (1987) Calciumcalmodulin-dependent protein kinases. In: Calcium and cell function, Vol 7 (Cheung WY, ed), pp. 62-107. New York: Academic.

Lankford KL, DeMello FG, Klein WL (1988) D, dopamine receptors inhibit growth cone motility in cultured retina neurons: evidence that neurotransmitters act as morphogenic growth regulators in the developing central nervous system. Proc Natl Acad Sci USA 85:2839 2843.

Lipton SA, Kater SB (1989) Neurotransmitter regulation of neuronal outgrowth, plasticity and survival. Trends Neurosci 12:265-270.

Lipton SA, Frosch MP, Phillips MD, Tauck DL, Aizenman E (1988) Nicotinic antagonists enhance process outgrowth by rat retinal ganglion cells. Science 239:1293-1296.

Manalan AS, Klee CB (1984) Calmodulin. In: Advances in cyclic nucleotide and protein phosphorylation research, Vol 18 (Greengard P, Robinson GA, eds), pp 227-278. New York: Raven.

Marcum JM, Dedman JR, Brinkley BR, Mcans AR (1978) Control of microtubule assembly-disassembly by calcium-dependent regulator protein. Proc Natl Acad Sci USA 75:3771-3775.

Mattson MP (1988) Neurotransmitters in the regulation of neuronal cytoarchitecture. Brain Res Rev 13:179-212.

Mattson MP, Kater SB (1987) Calcium regulation of neurite elongation and growth cone motility. J Neurosci 7:4034-4043.

Mattson MP, Dou P, Kater SB (1987) Pruning of hippocampal pyramidal neuron dendritic architecture in vitro by glutamate and a protective effect of GABA plus diazepam. Soc Neurosci Abstr 13: 367.

McCobb DP, Kater SB (1986) Serotonin inhibition of growth cone motility is blocked by acetylcholine. Soc Neurosci Abstr 12:1117.
McCobb DP, Kater SB (1988) Membrane voltage and neurotransmitter regulation of neuronal growth cone motility. Dev Biol 130: 599-609.

McCobb DP, Haydon PG, Kater SB (1985) Dopamine: an additional regulator of neurite outgrowth in Helisoma. Soc Neurosci Abstr 11: 761.

McCobb DP, Cohan CS, Connor JA, Kater SB (1988a) Interactive effects of serotonin and acetylcholine on neurite elongation. Neuron 1:377-385

McCobb DP, Haydon PG, Kater SB (1988b) Dopamine and serotonin inhibition of growth cone motility of different identified neurons. $J$ Neurosci Res 19:19-26.

Means AR, Tash JS, Chafouleas JG (1982) Physiological implications of the presence, distribution, and regulation of calmodulin in eukaryotic cells. Physiol Rev 62:1-39.

Murawsky M, Suszkiw JB (1984) Effects of trifluoperazine on $\mathrm{K}^{+}$ stimulated $\mathrm{Ca}^{2+}$ influx and ${ }^{3} \mathrm{H}-\mathrm{ACh}$ release in synaptosomes. Soc Neurosci Abstr 10:197.

Norman JA, Ansell J, Stone GA, Wennogle LP, Wasley JWF (1987) CGS 9343B, a novel, potent, and selective inhibitor of calmodulin activity. Mol Pharmacol 31:535-540.

Patterson PH (1988) On the importance of being inhibited, or saying no to growth cones. Neuron 1:263-267.

Pearce IA, Cambray-Deakin MA, Burgoyne RD (1987) Glutamate acting on NMDA receptors stimulates neurite outgrowth from cerebellar granule cells. FEBS I ett 223:143-147.

Roufogalis BD (1982) Specificity of trifluoperazine and related phenothiazines for calmodulin-binding proteins. In: Calcium cell function, Vol. 3 (Cheung WY, ed), pp 129-159. New York: Academic.

Safayhi H, Kuhn M, Koopmann I, Ammon H (1989) CGS 9343B and W-7 (calmodulin antagonists) inhibit $\mathrm{KCl}$-induced increase in cytosolic free calcium and insulin secretion of RINm5F cells. Naunyn Schmiedebergs Arch Pharmacol 339:8-13.

Schatzman RC, Wise BC, Kuo JF (1981) Phospholipid-sensitive calcium-dependent protein kinase: inhibition by antipsychotic drugs. Biochem Biophys Res Commun 98:669-676.

Schatzman RC, Raynor RL, Kuo JF (1983) N-(6-aminohexyl)-5-chloro-1-napthalene-sulfonamide (W-7), a calmodulin antagonist, also inhibits phospholipid-sensitive calcium-dependent protein kinase. Biochim Biophys Acta 755:144-147.

Schulman $\mathrm{H}$ (1984) Phosphorylation of microtubule-associated proteins by a $\mathrm{Ca}^{2+} /$ calmodulin dependent protein kinase. J Cell Biol 99: 11-19.

Sobue K, Fujita M, Muramoto Y, Kakiuchi S (1981) The calmodulin binding protein in microtubules is tau factor. FEBS Lett 132:137140.

Wong RG, Hadley RD, Kater SB, Hauser GC (1981) Neurite outgrowth in molluscan organ and cell cultures: the role of conditioning factor(s). J Neurosci l:1008-1021.

Yamamoto H, Fukunaga K, Tanaka E, Miyamoto E (1983) $\mathrm{Ca}^{2+}$ and calmodulin-dependent phosphorylation of microtubule-associated protein 2 and tau factor, and inhibition of microtubule assembly. $\mathbf{J}$ Neurochem 41:1119-1125.

Yamamoto H, Fukunaga K, Goto S, Tanaka E, Miyamoto E (1985) $\mathrm{Ca}^{2+}$ calmodulin-dependent regulation of microtubule formation via phosphorylation of microtubule-associated protein 2, tau factor, and tubulin and comparison with the cyclic AMP-dependent phosphorylation. J Neurochem 44:759-768.

Yamauchi T, Fujisawa $\mathrm{H}$ (1982) Phosphorylation of microtubuleassociated protein 2 by calmodulin-dependent protein kinase (kinase II) which occurs only in the brain tissues. Biochem Biophys Res Commun 109:975-981.

Yamauchi T, Fujisawa H (1983) Disassembly of microtubules by the action of calmodulin-dependent protein kinase (kinase II) which occurs only in the brain tissues. Biochem Biophys Res Commun 110: 287-291.

Yamauchi T, Fujisawa H (1988) Regulation of the interaction of actin filaments with microtubule-associated protein 2 by calmodulin-dependent protein kinase II. Biochim Biophys Acta 968:77-85. 